\title{
Economic Empowerment for Rural Women in Nigeria: Poverty Alleviation through Agriculture
}

\author{
Esther F. Fabiyi ${ }^{1}$ \& Kemi E. Akande ${ }^{2}$ \\ ${ }^{1}$ Department of Agricultural Economics and Extension, College of Agricultural Sciences, Landmark University, \\ Omu-Aran, Kwara State, Nigeria \\ ${ }^{2}$ Department of Animal Production, Faculty of Agriculture, Abubakar Tafawa Balewa University, Bauchi State, \\ Nigeria \\ Correspondence: Esther F. Fabiyi, Department of Agricultural Economics and Extension, College of Agricultural \\ Sciences, Landmark University, Omu-Aran, Kwara State, Nigeria. E-mail: esfabiyi@yahoo.co.uk
}

Received: May 25, 2015 Accepted: June 24, 2015 Online Published: August 15, 2015

doi:10.5539/jas.v7n9p236 URL: http://dx.doi.org/10.5539/jas.v7n9p236

\begin{abstract}
Generally, rural women are majorly involved in agricultural activities such as planting, weeding, harvesting, processing and marketing. They also keep some domestic animals and birds. Empowering rural women will go a long way to improving the economic life of the women and also the well-being of individuals, families and the rural communities. Social, cultural traditions and agricultural constraints can limit rural women's economic status. Rural women's limited access to productive resources, low educational level and illiteracy are contributors to rural women's poverty. Illiteracy affects their chances to benefit from newer, non-traditional methods such as: information and communication technologies. The promotion of agricultural development should be through the provision of useful and relevant information to the farming communities by the extension services. The unpaid work that women perform at home and farm are not recognized for official record. There are many constraints making rural women farmers to be lagging behind economically, apart from lack of agricultural information. The main constraints are the lack of personal land and credit. There is evidence that empowering women in multiple ways will contribute to their own food security and nutrition and that of their families. Women are limited in terms of their potential in contributing to agricultural development. Reducing the gender disparities or discrimination will generate significant gains for the agricultural sector. There is the need for national laws and policies that promote women's rights to own land, property and have equal access to credit for their businesses.
\end{abstract}

Keywords: agriculture, food, empowerment, women, poverty

\section{Introduction}

The major occupation of the rural people in Nigeria is farming. Women in rural communities play significant roles in achieving the transformation necessary for economic and social changes for sustainable national development. The Food and Agricultural Organization (FAO, 1995) cited by Lo (2000) reported that rural women constitute $70 \%$ of the agricultural workers, $60-70 \%$ of the labour, $80 \%$ of food storage and transportation from farm to village and $60 \%$ of the harvesting and marketing. Despite all these activities majority of rural women are still poor. It is noteworthy the remarkable part that women play in many developing countries in agricultural development (Egbugara, 1993). Generally, women are majorly involved in food cultivation, production, processing, preparation and marketing despite these activities women contribution to food and agricultural production are still largely underestimated. Many programmes fail to recognize the diversity of women's life experiences. However, a holistic approach is rarely used to understand and address the many forms of discrimination and inequality that affect them in relation to food security (Goetz, 2007).

Various strategies have been used to develop women through different programmes by the Federal Government. However, these programmes are short-lived, sometimes due to change of government. Also, the programmes may not have been carried out in a manner that meets the needs of the rural women. Some of these programmes were: Better life for rural women, poverty alleviation and presently women empowerment. This may also be abandoned by the new government. The lack of continuity of government programmes and policies has been a major problem causing setbacks in rural development, which in essence also has negative effects. 
Economic status has always been used as a measure to categorize male farmers, but more often female farmers have been regarded as a homogenous group who are only distinguished by gender. Their productive economic roles are regarded as part of their domestic roles (Egbugara, 1990). It is assumed that when the economic prosperity of their husbands improves, then the economic status of the wives will also improve, this is not always applicable to all women, especially rural women.

In rural communities, the occupational structure is characterized by those enterprises considered acceptable to the women folks through socio-cultural norms and practices. The enterprises have impacts on the stability of the household, the progress of the village and rural communities. The income of farmers in Nigeria is determined by the market price offered to agricultural products. In most part of the northern states in Nigeria, religion and tradition prohibit women from participating in open marketing. The majority of people selling items in the market in that part of the country are men. The few women selling are from other parts of the country.

\section{Discussion}

\subsection{Food and Nutrition Security through Agriculture}

Malnutrition is a major issue and of great concern in the poorest countries of the world and is closely associated with overall low food intake both in quantity and quality. Sub-Saharan Africa has the highest percentage of those undernourished (approximately one in four people) though that number varies by country (FAO, 2014).

Agriculture can play a central role in addressing the issue of poverty and food security. It is, therefore, necessary for government leaders, policymakers and development practitioners to support and make the improvement of agricultural productivity a priority in their agenda, because it is paramount to achieving the desired food and nutrition security targets. In most developing countries, agriculture is one of the major pillars of the economy. Encouraging agricultural based innovative ventures will help the advancement of women in rural areas. It is, therefore, needful to empower rural women through agricultural policies that assist them take care of their needs and alleviate poverty.

In most of the developing countries, women participate in the production of vegetables under the home-based and backyard gardening. Also, they are involved in the keeping and rearing of rabbits, goats, poultry birds (chicken, duck, guinea fowl), pigs and fish are being raised and managed at home by women. These agricultural activities are carried out by women in order to raise the nutritional status of their households (Fabiyi, 2015).

\subsection{Women's Contribution to Agricultural Development}

Globally, women contribute remarkably to the rural economy and agricultural activities in many developing countries (FAO, 2010a). According to the reports of FAO (2010b) the agricultural share of economically active women was $65.0 \%$ in Sub-Saharan Africa in 2010. While in Nigeria the agricultural share of economically active women was reported to be $26.8 \%$ in 2010 .

The economic role of women in farming cannot be compared with that of men. The labour of women starts from the time of cultivation to the time of marketing of the farm products. Selling of the farm produces for income is done mainly by women, especially in the southern part of Nigeria. This shows the importance of women in farming business. One of the most significant roles is earning income from the farm produce.

Women are largely responsible for production that benefits local consumption, such as maize, groundnuts, legumes and vegetables on smaller farms. The lands are culturally obtained from husbands, fathers or/and other close relatives. Women have no personal land for farming. Women sometimes have to pay men labourers to do some tasks that they may not be able to perform; such as land preparation and heap making for root crops. Women are not paid for working on family farms, self-employed producers, on and off employees, traders and providers of services (Hill, 2011). Women also play a key role in food and agricultural processing at home and community levels. This processing work is vital for making raw grains, roots, tubers, pulses, vegetables, milk, fish and other products into nutritious and acceptable form, safe food, yet it is often not recognized, documented or appreciated.

In many rural communities in Nigeria, women are involved in processing of farm produce as well as marketing the agricultural products as self-employment and thereby enhancing the financial status of their family. These women prepare and sell cooked foods, local beverage drinks and snacks for example bean cake, groundnut cake, buns and yoghurt. In some part of northern Nigeria, the rural nomadic Fulani women milk the cows and process the milk collected into yoghurt, cheese and butter on a relatively large scale basis for marketing. It has been observed that it is virtually the processed milk and its processed products that sustain the Fulani family in Nigeria (Amedzo, 1988). 
The United Nations Food and Agriculture Organization (FAO) reports that women comprise about $43 \%$ of the agricultural labour force in developing countries. The percentage is as high as or even higher than $80 \%$ in some countries in Sub-Saharan African countries (FAO, 2011). The majority of food production that is attributable to women makes them the true agents of food security and household welfare in rural areas.

In Nigeria, women work more than men in the cocoa plantations, in coffee production for export and in marketing crops such as rice, maize and cassava (Fresco, 1998). In spite of this heavy involvement, evidence from studies has shown that rural women are usually disadvantaged in their access to all factors of agricultural production, marketing and processing. In Nigeria, male farmers enjoy extension services and agricultural information more than female farmers.

Apart from relegation, there are many constraints that make women poor despite their enormous potentials in farming. Some of the constraints are: lack of farming implements and equipment, lack of access to land, lack of credit or limited capital for farm operations. Empowerment of rural women should be done directly from the federal government to the rural women. It should not go through state or local governments in order to prevent diversion or delay. Therefore, the main objective of this study is to suggest ways to improve rural women's economic status through agricultural activities; specific objectives are to:

$>$ Identify major constraints hindering rural women's economic status.

$>$ Identify areas of their contributions to agricultural development in the country and

$>$ Explain reasons why they remain poor despite all their labours.

\subsection{Reasons and Causes of Poverty among Rural Women in Nigeria}

Women comprise the majority of the poor. They constitute the majority of unpaid productive workers through their labour on family farms and other domestic activities (UNDESA, 2010). Yet they are usually expected to manage their families' nutritional needs in the face of these constraints and poverty (Holmes, Jones \& Marsden, 2009; World Bank/FAO/IFAD, 2009). Their productive capacity is also being undermined due to their lack of access to productive resources such as land, seeds, and credit (IDS, 2014).

In spite of their effort and immense contributions to agriculture, rural women are still among the relegated groups in the society and the poor. In Nigeria, women are relegated in various ways. In some homes, women have no say in matters pertaining family finance or even access to family finance. Likewise in urban areas Nigerian women also experience gender discrimination and relegation, for instance, in offices men occupied the key positions and in the nation, whereas, women have to cry out or lobby before few of them are given reasonable positions.

According to Federal Office of Statistics (FOS, 1999), about 73\% of the female farm holders in Nigeria are poor. In addition to the lack of agricultural farm equipment and land constraints, lack of support from their husbands can lead to the lack of success in their farm activities. A woman can do very little without the husband's emotional, physical and financial support. In addition, psychologically and socially some husbands may create barriers for their wives economic success when they notice that they are economically successful more than them. This is one of the major problems hindering many women's progress in life. It should be noted that the economic improvement of women will also lead to the improvement of almost all aspects of the family wellbeing, particularly the nutritional status of the family. If a woman is poor it will reflect in the diet of the family, but if she is economically buoyant she will ensure the food security of her household. The notion of males as breadwinners and the females as housewives has made men occupy the best position with high economic benefit than women. Less attention is given to rural women farmers needs when compared to men farmers, with regards to the provision of agricultural extension services. These women are assumed to play the supportive role as farmers' wives and they are, therefore, most often neglected and not involved in the agricultural programmes (Samanta, 1994).

\subsection{Rural Women's Constraints in Agricultural Production and Marketing}

Rural women in developing countries (including Nigeria) have been found to play a major role in agricultural activities in the areas of food production and marketing. In the Northern part of Nigeria, most rural women do not farm or sell agricultural produce but do more processing. Men are more involved in agricultural activities than women because women are in partial or total seclusions in the Islamic States. Other constraints limiting rural women's agricultural productivity are land tenure system, lack of access to loans, illiteracy, multiple family responsibilities and other cultural, religious barriers and also the way that agricultural services are staffed, managed and designed (Jiggins, 1989; Olawoye, 1989; FAO, 1993). Many rural women may not have access to improved technologies and innovations, agro-chemicals and fertilizers which are essential for agricultural 
business. It is important that women's enormous contribution to agriculture be recorded, recognized and encouraged. There must be a deliberate effort to empower women to release their potentials, energies and production abilities. The Women in Agriculture (WIA) under the control of Agricultural Development Projects (ADP) need to focus more on policies and organise programmes targeted towards effectively addressing the problems or constraints of women farmers in the agricultural production in rural areas. The new extension perspective must address emerging local and global issues in order to be relevant to meet the needs of the people. The imbalance in agricultural extension services needs to be improved. In Nigeria, there are more male extension agents than females and they pay attention more to male farmers (Spence, 2001).

\subsection{Importance of Women's Education in Agriculture and Rural Development}

Agriculture in most developing countries of the world is a major key in enhancing food security and reducing the level poverty. Women account for more than half of the world's agricultural production, in spite of this fact, the men folks have access to more training than women. Agricultural and enterprise training for women is crucial for improving their farm yields and raise their living standard (CSD, 2009).

Rural women tend to be disadvantaged compared with men because they have less education, capital and they cannot easily obtain credit. The Nigeria's philosophy of education is based on the integration of the individual into a sound and effective citizen and equal educational opportunities for all citizens of the nation from primary to tertiary levels (Fabiyi, 2015). There is the need for a type of education which must equip the receiver with necessary skills to face the challenging situations which can be economic, social, political and cultural in nature.

Education and training are essential tools necessary for alleviating poverty and hunger. Women that are educated have a more likelihood to be healthier, have better earnings and exercise greater decision-making power within the household than the illiterate women (IDS, 2014). Educated women are also more likely to make sure that their children go to school. From a development perspective, investing in girls' education has the highest rate of returns of any possible investment in developing countries (IDS, 2014). Education and training are crucial to the improvement of agricultural and non-farm productivity and reducing household poverty levels.

Nigerian women like all women all over the world, especially in most developing countries, continue to face several forms of discrimination which stands as hindrances to developing to their full potential (Okebukola, 2001). In the northern part of Nigeria, opportunities for participation in education are less for girls than for boys. When the girls grow up and become women, lack of education becomes compounded leading to social and economic backwardness. One of the main barriers holding back the advancement of women in Nigeria is the high level of female illiteracy (Federal Office of Statistics, 2000 cited by Okebukola, 2001). According to Adekanye (1985), education of women provides an instrument for integration into development and for enhancing their contribution in the rural economy. Sound education can bring about change in behaviours, adoption of new technology in farming, creativity in handcraft and in food security.

\section{Conclusion and Recommendations}

In Sub-Saharan Africa, 43.8\% of women accounted for economically active population, in 2010, and in Nigeria, the women share of the economically active population was $36.9 \%$ in the same year according to the reports of FAO (2010b).

There is the need for empowering women in their roles as caregivers and household keepers which is a crucial factor for enhancing food security and nutritional living standard for themselves and for their children. In recent times, gender issues are now gradually being looked into as it affects agricultural and economic development of the rural economy. African women's involvement in farming and handcraft shows that they are physically and intellectually capable of economic independence (Yahaya, 2002). It is necessary for women to live independent financial life and reduce the dependence on their husbands.

$>$ More research should be conducted on rural women's poverty and female farmers' relationship with their husbands in farm productions.

$>\quad$ There is the need to ensure involvement of full participation of women who are poor and are less educated in agricultural business.

> There should be provision for agricultural innovations and technologies to be practically used in the field.

$>$ Women farmers' seminars should be organized to share with researchers and field staff their technical problems specific to women farmer's production systems.

Women should be taught and encouraged to engage in large-scale farming and not only sustenance farming, especially as it pertains to food crops, vegetables, fruits and fishery businesses. Financial empowerment should 
be given to rural women farmers. These should be done directly from the federal government to the rural women. It should not go through the state and local governments. Governments should meticulously and systematically carry out the empowerment programmes for rural women. This will greatly reduce the poverty level among rural women farmers and others.

$>$ Attention should be paid to the untapped productive potential of rural women in Nigeria.

$>$ Awareness should be raised about women as agents of food production and that constraints to women productivity should be reduced through land rights legislation, compensation for unpaid work and access to credit for farming.

$>$ There should be the establishment of business training and schemes in villages and remote rural areas to assist women in the management of their savings to support their own business enterprises.

$>$ Creation of drop-in-sessions where women can ask questions and get advice on how to go about their agricultural practices and their business enterprises.

$>$ The federal government should encourage and initiate the development of rural women's self-help and savings groups

$>\quad$ The government should build rural storage facilities for proper storage of their farm produce in order to prevent spoilage and wastage of resources.

> Gender sensitivity is essential when carrying out programmes, training and workshops in rural settings.

Poverty alleviation of the Nigerian rural women can be achieved majorly by supporting and bringing about improvement in their agricultural activities and implementing policies the will empower them and enhance productivity. Additionally, the government can provide education and vocational training, enterprise development training, financial empowerment (micro-credit), improved extension services and special agricultural technologies for rural women farmers. All these will consequently result in a better standard of living and improved economic status of the Nigerian rural women as well as their household.

\section{References}

Adekanye, T. O. (1985). The Nigeria rural women: some considerations for development. The Nigeria Journal of Agricultural Extension, 3, 45-53.

Amedzo, A. K. (1988). African Farming and Food Processing Magazine (March/April, p. 49).

CSD (City \& Guilds Centre for Skills Development). (2009). Training for Rural Development: Agricultural and Enterprise Skills for Women Smallholders. Kathleen Collett \& Chris Gale. Editor: Sara Clay. Retrieved from http://t4rd.skillsdevelopment.org/pdf/Training\%20for\%20rural\%20development.pdf

Egbugara, C. A. (1990). An Analysis of the Role or Rural Women in Production and Procession of Selected Food Crops in Etiti Local Government Area of Imo State, Nigeria (Ph.D Thesis, Unpublished. Ibadan: University of Ibadan).

Egbugara, C. A. (1993). Economic status and rural women's involvement in agricultural in Imo State. Journal Rural Extension and Development, 1, 87-93.

Fabiyi, E. F. (2015). Home Economics for Agricultural Sciences in Tertiary Institutions (p. 197). Ibadan, Abbey Printing Press.

FAO (Food and Agriculture Organisation). (2010a). Roles of women in agriculture. Prepared by the SOFA team and Cheryl Doss, Rome.

FAO (Food and Agriculture Organisation). (1993). Agricultural extension and farm women in the 1980's. Rome: FAO.

FAO (Food and Agriculture Organisation). (2010b). FAOSTAT statistical database. Retrieved from http://faostat.fao.org

FAO (Food and Agriculture Organisation). (2011). Women in agriculture: Closing the gender gap. State of Food and Agriculture Report, 2010-11. Rome: FAO.

FAO (Food and Agriculture Organisation). (2014). The State of Food Insecurity in the World: Strengthening the Enabling Environment for Food Security and Nutrition. Rome: FAO. Retrieved from http://www.fao.org/3/a-i4030e.pdf

FOS (Federal Office of Statistics). (1999). Poverty and agricultural sector in Nigeria. Federal Office of Statistics, 
Nigeria.

Fresco, L. O. (1998). Higher agricultural education: An opportunity in rural development for women (p. 4). Sustainable development department, food and agricultural organization (FAO), for the United Nations.

Goetz, A. M. (2007). Gender justice, citizenship and entitlements - Core concepts central debates and new directions for research, In M. Mukhopadhyay \& N. Singh (Eds.), Gender justice citizenship and development. Ottawa: International Development Research Centre.

Hill, C. (2011). Background paper' prepared for UN Women Expect Group Meeting on Enabling Rural Women's Economic Empowerment: Institution, Opportunities and Participation. New York: UN women.

Holmes, R., Jones, N., \& Marsden, H. (2009). Gender vulnerabilities, food price shock and social protection responses. ODI background Note, London: ODI.

IDS (Institution of Development Studies). (2014). Availability of food and nutrition (p. 104). IDS Bridge development gender.

Jiggins, J. (1989). How poor women earn income in sub-Saharan Africa and what works against them. World Development, 17(7), 953-963. http://dx.doi.org/10.1016/0305-750X(89)90160-5

Lo, M. (2000). Women in Agriculture in Sub-Saharan, Africa (p. 20). Retrieved from http://trochim.humanconell edu/gallery/lo/personal\%20web\%htm

Okebukola, P. (2001). Women's education, employment and access to resources. Children's and women's rights in Nigeria: A wake-up call (pp. 177-184).

Olawoye, J. A. (1989). Difficulties for rural women in securing resources for agricultural production: Two case studies from Oyo state. Nigeria Rural development in Nigeria, 3(2), 77 -81.

Samantha, R. K. (1994). They reap less than they sow. The Hindu Madra, India.

Spence, N. (2001). Gender mainstreaming in agriculture and rural development: A reference manual for governments and other stakeholders (p. 46).

UNDESA (United Nations Department of Economic and Social Affairs). (2010). The World's Women 2010: Trends and Statistics. New York: UN.

World Bank/IFAD/FAO. (2009). Gender and Agriculture Sourcebook: Investing in Women as Drivers of Agricultural Growth. Washington, DC: World Bank.

Yahaya, M. K. (2002). Gender and communication variables in agricultural information dissemination in two agro-ecological zones of Nigeria (p. 68).

\section{Copyrights}

Copyright for this article is retained by the author(s), with first publication rights granted to the journal.

This is an open-access article distributed under the terms and conditions of the Creative Commons Attribution license (http://creativecommons.org/licenses/by/3.0/). 